\title{
8
}
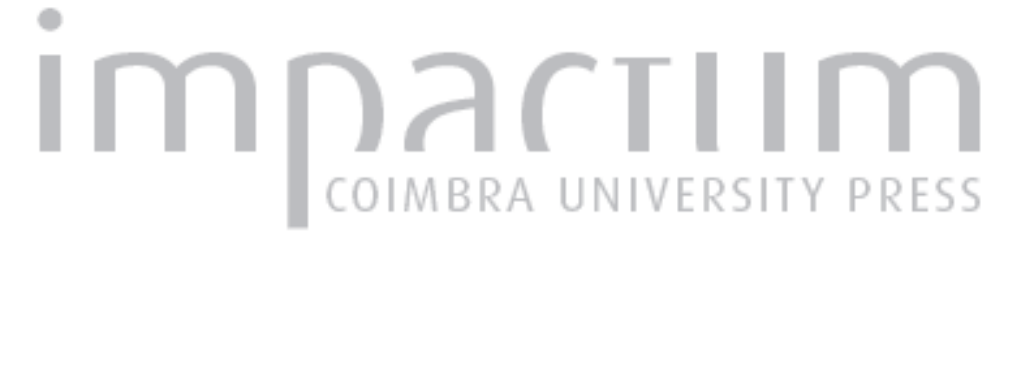

Casos de violência em ambiente eclesiástico: contributo do Bulário Português (sécs. XII-XIII)

Autor(es): $\quad$ Marques, María Alegría Fernandes

Publicado por: $\begin{aligned} & \text { Instituto de História Económica e Social; Imprensa da Universidade de } \\ & \text { Coimbra }\end{aligned}$

URL

persistente:

DOI: $\quad$ DOI:https://doi.org/10.14195/0870-4147_37_14

Accessed : $\quad$ 26-Apr-2023 13:19:09

A navegação consulta e descarregamento dos títulos inseridos nas Bibliotecas Digitais UC Digitalis, UC Pombalina e UC Impactum, pressupõem a aceitação plena e sem reservas dos Termos e Condições de Uso destas Bibliotecas Digitais, disponíveis em https://digitalis.uc.pt/pt-pt/termos.

Conforme exposto nos referidos Termos e Condições de Uso, o descarregamento de títulos de acesso restrito requer uma licença válida de autorização devendo o utilizador aceder ao(s) documento(s) a partir de um endereço de IP da instituição detentora da supramencionada licença.

Ao utilizador é apenas permitido o descarregamento para uso pessoal, pelo que o emprego do(s) título(s) descarregado(s) para outro fim, designadamente comercial, carece de autorização do respetivo autor ou editor da obra.

Na medida em que todas as obras da UC Digitalis se encontram protegidas pelo Código do Direito de Autor e Direitos Conexos e demais legislação aplicável, toda a cópia, parcial ou total, deste documento, nos casos em que é legalmente admitida, deverá conter ou fazer-se acompanhar por este aviso.

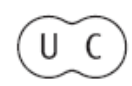




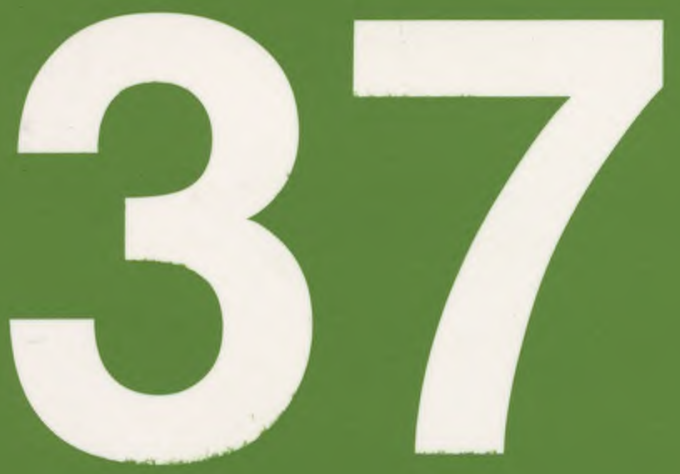

Revista Portuguesa de História

Faculdade de Letras da Universidade de Coimbra Instituto de Historia Econónica e Samial

Coimbra 05 
Revista Portuguesa de Historia

t. XXXVII (2005)

pp. 343-360

\section{Casos de violência em ambiente eclesiástico. Contributo do Bulário Português (sécs. XII-XIII)}

1. A abordagem historiográfica do fenómeno da violência ${ }^{1}$, no que diz respeito a tempos medievais e tendo como protagonistas membros do clero, tem como referência, entre nós, as lutas entre o clero e a realeza. Os estudos sobre a matéria não são feitos na perspectiva do fenómeno social em si mesmo, mas enquanto manifestação do antagonismo entre os poderes que esses dois grupos detinham e protagonizavam ${ }^{12}$. De facto, há sobejos casos, por demais conhecidos, para que seja necessário chamar o testemunho de exemplos.

Contudo, não é da violência protagonizada por membros dos grupos dominantes da sociedade, na sua relação mútua, mas antagónica, que iremos ocupar-nos ${ }^{3}$.

É, antes, de casos de violência ocorridos em ambiente eclesiástico, fazendo deste uma interpretação lata, que nos permita considerar não só as instituições em si e nos seus membros mas, principalmente, na relação entre si.

1 Sobre este conceito e as suas várias conotações e associações ver Alain Birou, Dicionário de Ciências Socais. Lisboa, Círculo de Leitores, 1988, s. v. "Conflito", "Oposição social", "Violência".

2 Sobre este tema, ver a muito completa síntese de José Antunes, António Resende de Oliveira e João Gouveia Monteiro, Conflitos politicos no reino de Portugal entre a Reconquista e a Expansão. Estado da questão. Separata de Revista de História das Ideias, vol. 6 (1984), pp. 25-131.

3 Sobre esta temática em tempos medievais, veja-se, neste volume, o trabalho de Maria Teresa Nobre Veloso. 
Este entendimento permite-nos uma leitura do fenómeno e o estabelecimento de urna tipología muito alargada das variadíssimas ocorrências. Poderemos, pois, considerar os casos das instituições eclesiásticas propriamente ditas, quando a violência se instala nelas mesmas, com conflitos portas adentro, ou quando os seus interesses se chocam e, em vez do relacionamento pacífico surge a discórdia, o litígio e a violência nas suas relações.

Além deste sentido institucional que a violência pode assumir, o fenómeno pode ainda considerar-se sob o ponto de vista dos seus protagonistas, isto é, a violência tanto pode ser protagonizada por membros das instituições como provocada por eles, mas levada a cabo por outros. Nestes casos, por regra, as consequências fazem-se sentir sobre as instituições (e os seus membros) já de si em litígio, como podem chamar à colação outros, leigos, quando se repercutem sobre instituições que, sendo eclesiásticas, os enquadram a eles, como são as paróquias. E porque, neste caso, já nos encontramos em presença de ocorrências que vão além da instituição, para se volverem em vivências sociais, entendemos poder estender a análise aos casos de violência sobre clérigos e religiosos, exercida por elementos leigos da sociedade. Em determinadas circunstâncias, quando se exerce sobre membros do clero regular, pode tratar-se também, afinal, de violência em pleno ambiente eclesiástico.

Por norma, o estudo do fenómeno da violência enquadrado desta forma é passado em silêncio na historiografia. Não por serem desconhecidos os casos que o ilustram, mas porque enquadrados noutra óptica de análise, que não o fenómeno em si mesmo, e porque podem provocar escândalo, numa óptica mais puritana de consideração das questões a abordar pela historiografia, sobretudo tratando-se de instituições eclesiásticas, uma vez que os casos ferem a imagem estereotipada do clérigo, seja secular, seja regular. Contudo, valem aqui as palavras de S. Gregorio: "se a verdade pode provocar o escândalo, é mais útil permitir o escândalo que omitir a verdade"4.

2. De todas as situações referidas acima se conhecem algumas situações, mais ou menos significativas, mais ou menos marcantes, fixadas em documentos normalmente redigidos com outro fim que não fosse deixar memória de comportamentos menos próprios do grupo clerical. Cremos que qualquer estudioso da Medievalidade já se cruzou com casos desta natureza, nas suas pesquisas de arquivo.

4 Citado por A. Dimier, "Violences, rixes et homicides chez les Cisterciens», in Mélanges à la mémoire du Père Anselme Dimier présentés par Benoît Chauvin. I. Père Anselme Dimier. 2. Travaux inédits et rééditions, Benoît Chauvin, 1987, Pupillin - Arbois, pp. 575-585. 
Pela nossa parte, conhecemos alguns casos de muito interesse não só sob o ponto de vista da história das instituições eclesiásticas, mas também para a compreensão do próprio povoamento e ordenamento do território e do desenvolvimento das actividades económicas do reino de Portugal.

Porém, há muito que nos chama a atenção todo um conjunto de actos conotados com variadas formas de violência, que estão espelhados ao longo das páginas de uma obra em que, há anos, tivemos a honra de colaborar. Por isso, elegemo-la, hoje, como fonte para o nosso estudo 5 . Sendo de claro cunho eclesiástico, apresenta-se bastante ecléctica, pois abarca o horizonte possível da vida e das instituições eclesiásticas. É ela o Bulário Português, no seu primeiro (e, até ao momento, único) volume publicado, o relativo ao pontificado de Inocêncio III 6 .

Esta fonte, que contém 228 documentos do pontificado de Inocêncio III (1198-1216), todos eles de interesse a Portugal, apresenta um enorme número de casos cujo assunto se prende com formas e acções em que a violência esteve patente.

Aliás, nela, a palavra violentiam (violenciam; vehementiam) é usada muito frequentemente, por vezes mesmo sem um conteúdo concreto atribuído. Mas que significado assumia? Ao lermos os documentos em que há essas ocorrências, ficamos com a ideia de que era uma noção muito ampla, onde cabiam casos concretos de crime, como o roubo (rapinam; furtum; spoliationem; subtractionem), a violação de domicílio (domum intrare vi) e o homicidio (interfectionem hominis), e ainda um conjunto de práticas que, ligadas todas elas a uma noção de violência, se expressam por termos vários. São termos polissémicos, cujo conteúdo

5 E assim deixamos para outra ocasião esses casos, de que, um deles, do mosteiro de Lorvão, particularmente também nos interessa.

6 Avelino de Jesus da Costa e Maria Alegria Femandes Marques, Bulário Português. Inocêncio III (1198-1216). Coimbra, Instituto Nacional de Investigação Científica - Centro de História da Sociedade e da Cultura, 1989. É de justiça que aqui se deixe mais uma nota de pública homenagem ao trabalho do nosso saudoso Mestre, Professor Doutor Cónego Avelino de Jesus da Costa, autor e obreiro deste projecto, no qual trabalhou especifícamente durante alguns anos, como bolseiro da Fundação Calouste Gulbenkian. Também de público agradecimento pela iniciação que nos proporcionou nesta temática e pela honra que nos deu de podermos ser, com ele, co-autora do volume que deixou publicado e que elegemos como fonte deste nosso trabalho. Como bom investigador que era, e como poderá ver-se por esta obra publicada, nunca abandonou esse trabalho. Basta confrontar esse volume publicado com o relatório (348 páginas) que deixou entregue na Fundação Calouste Gulbenkian para disso se ter exacta medida. Pela parte que nos toca, como sua discipula, boa conhecedora do seu exemplar desse relatório, devemos dizer que ele é uma pálida imagem do que foi o verdadeiro inventário do Bulário Português do séc. XIII que esse eminente Mestre deixou. Este conta, no mínimo, 35\% a mais que essa primeira versão. Por isso, publicar, alguma vez e tão-só, o exemplar depositado na Fundação Calouste Gulbenkian, sendo bom, seria, quando menos, amputar a verdadeira dimensão da sua obra e atraiçoar a sua memória. 
é difícil de determinar, de concretizar, na forma e no modo. Exprimem a ideia de ofensa (verbal e corporal), espancamento (percussionem), força (vim; fordam), tortura (tormentum; violenter extorsionem), incitamento à destruição (incitans ad destruendum), incómodo físico (molestationem), malícia (maliciam), injúria (injuriam; contumeliam), opressão e agravo (gravamen), prejuízo (detrimentum; lesionem; jacturam; prejudicium), profanação do sagrado (invadere altarem et ad terram viliter deicere), usurpação (usurpationem), violência ao sepultar (corpus defuncti auferentes armata manu sepeliri) ${ }^{l}$. Muitas vezes, é utilizada a simples palavra violência para exprimir uma ideia algo difusa, que configuraria situações diversas, mas onde algumas das práticas anteriormente referidas podiam estar presentes. Outras vezes, percebe-se que o documento enquadrando, na letra, a falta de obediência às normas do direito pretende ir muito mais longe, procurando prevenir alguma violência que essa falta podia arrastar.

Isto é, nos documentos do papa Inocêncio III relativos a Portugal detecta-se, explícita ou implicitamente, todo um conjunto de atitudes que configuram violência, seja expressa em palavras ou actos de mais ou menos força ou brutalidade 778 , exercidos, estes, normalmente por meios físicos, por pessoas afectas a instituições, em antagonismo declarado relativamente a interesses que as opunham.

Por certo, poderão considerar-se graus ou variações nos diversos tipos de violência captados destes documentos, mas nem sempre é fácil estabelecê-los. Tanto mais quanto, muitas vezes, como ficou dito, não há concretização dos actos chamados de violência.

Parece-nos ainda importante chamar a atenção para o facto de o grupo social de que nos ocupamos apresentar características que podem tomar especial a consideração do fenómeno da violência nos casos que se lhe ligam. Por exemplo,

7 Sobre o vocabulário da violência, ainda que tendo por base outro tipo de fontes, ver Marie Rose Bonnet, "Le vocabulaire de la violence tel qu'il apparaît dans quelques textes non littéraires du XIVème et du XVème siècle en Provençal", in La violence dans le monde médiéval. Centre Universitaire d'Études et de Recherches Médiévales d'Aix, Aix-en-Provence, 1994, pp. 69-83. Sobre o conceito de insulto, ver Dominique Lagorgette, "Termes d'adresse, acte perlocutaire et insultes: la violence verbale dans quelques textes des XIVe, $\mathrm{XV}^{\mathrm{e}}$ et XVI $\mathrm{I}^{\mathrm{e}}$ siècles", in ibidem, pp. 317-332, maxime, 324-330. Ainda, sobre questões envolvendo membros do clero em cenas menos recomendáveis, em que a violência teve presença, ver Peter Linhean, Les dames de Zamora. Secrets, stupre et pouvoirs dans VEglise espagnole du XIII siècle. Paris, Les Belles Lettres, 1998 e Ana Paula Pratas Figueira Santos, A fundação do mosteiro de Santa Clara de Coimbra (Da instituição por D. Mor Dias à intervenção da Rainha Santa Isabel). 2 vols., Coimbra, Faculdade de Letras, 2000 (ao que nos interessa, ver I, pp. 124-134) (dissertação de mestrado; policopiada).

8 Sobre algumas formas de agressão (que são formas de violência), embora consideradas para meio urbano e sob uma perspectiva laica, ver María Luisa Bueno Domínguez, Dejando hablar a la Edad Media. Entre lo real y lo imaginado. Zamora, Editorial Semurte, 1999, pp. 47-56. 
quando uma instituição se recusava a pagar os direitos devidos a outra, não se trata, rigorosamente, de um caso de violência, mas de um desrespeito que pode configurar resistência mais ou menos activa ou passiva à instituição reclamante e pode levar a situação ou situações de violência ou entendidas como tal. Ou, o uso de um poder, o poder sancionatório da excomunhão ou do interdito, utilizado indistinta ou reiteradamente, podia configurar coacção psicológica, fonte de situações de desacordo, geradoras de conflito e violência. Isto é, toma-se muito ténue a fronteira entre a desobediência e o acto de violência.

3. Dentre as duas centenas de documentos publicados na fonte que nos serve de base de trabalho, encontram-se exemplos de todos os tipos de violência que assinalámos acima.

Comecemos pelos casos ocorridos no seio de instituições eclesiásticas. Embora o seu fim fosse, na essência, muito além da vida terrena e, muito mais, da própria vida quotidiana, o que é certo é que a realidade se lhes impunha e, por isso, elas não se mostravam incólumes às desavenças, às querelas, aos ódios, que fazem parte da condição humana. Os documentos pontifícios, mais prontos a mostrar caminhos que a acusar, permitem, muito mais, assinalar os casos que detectar a verdadeira origem e momento do conflito. Por certo, muitas vezes a origem nem seria um determinado acontecimento em si mesmo, mas ele representaria o culminar de pequenos incidentes que, avolumando-se, assumiam significado e faziam surgir situações de violência. Na circunstância, os casos ligam-se aos mosteiros de Pombeiro e de Santa Cruz de Coimbra, e ainda ao bispado do Porto e ao de Coimbra.

$\mathrm{O}$ primeiro caso prende-se com um clima de violência vivido no mosteiro de Pombeiro, provocada pela presença do próprio abade, um intruso, e caracterizada, no que agora nos importa, pela expulsão de vários monges e, maxime, pelo enforcamento de um deles, às mãos de um mouro escravo do mosteiro 9 .

Já no mosteiro de Santa Cruz, cujos membros protagonizaram ou provocaram muitos dos actos de violência expressos na fonte de que nos servimos, a própria comunidade não ficava isenta da notícia de alguma violência sobre os seus membros, nomeadamente quando deixavam bens à Sé de Coimbra; então, a expulsão era o destino do malquisto monge ${ }^{10}$. No entanto, o caso que mais se salienta prende-se com um diferendo entre um grupo de cónegos do mosteiro e as autoridades

9 Bulário Português. Inocêncio III(1198-1216), pp. 359-362, n. ${ }^{\circ} 203$. Doravante, citaremos apenas por Bulário...

${ }^{10}$ Ibidem, p. 149. 
do mesmo, sobre a apresentação e tomada de posse da capela de S. João, do mosteiro crúzio. Tal caso, chamando também à colação o bispo da cidade, corria já em 1209 na cúria pontifícia e aí se arrastava ainda em 1212. Pelo meio, contava com um gravíssimo incidente, que se saldou por uma violenta tentativa de homicídio, por parte de outros cónegos, da facção do prior, auxiliados por oficiáis da cidade, e perpetrada, com requintes de crueldade, a golpes de cutelo, sobre um dos cónegos da facção que se sentia atingida nos seus direitos sobre a capela ${ }^{11}$.

De modo mais suave, mas, na essência, não menos grave, se afiguraram as atitudes de alguns cónegos do Porto, para com o seu bispo, quando, no diferendo que opôs D. Martinho Rodrigues ao rei D. Sancho I, a propósito do senhorio da cidade e com causa próxima no casamento do príncipe D. Afonso com Urraca de Castela, o rei fez perseguir o bispo, que fugiu, "quasi nudus" para a Sé Apostólica. Sem poder concretizar-se as suas atitudes, apenas pode dizer-se que valeram que o papa os considerasse "... canonici Portugalensis ecclesie ecclesie quos ejus utpote boni patris oppressionibus compacti decuisset, non solum filialis compassionis dicuntur ei substraxisse solacium quinimmo tanto nocentiores aliis quanto pejus familiaris solet ledere inimicus, seviendi adversus ipsum temeritate suaprebuisse videntur extraneis incentivum..."11 12.

Bem diferente era a razão de queixa de alguns cónegos da Sé de Coimbra, a propósito dos actos do bispo D. Miguel. Os seus testemunhos deixam transparecer que, não estando de acordo com a carta de liberdade que esse bispo fez passar a favor do mosteiro de Santa Cruz, alguns deles não estariam dispostos a assiná-la, negando-lhe, assim, o seu aval. Porém, o bispo, ou os seus apoiantes, acharam forma de fazer mudar essa disposição, coagindo-os de diversas formas, de que uma, explícita, era a ameaça de privação dos benefícios ${ }^{13}$.

${ }^{11}$ Bulário..., pp. 270-272 e 333-336, n.08. 139 e 184, respectivamente.

12 Bulário..., pp. 279-280, n. ${ }^{\circ} 144$.

13 Ibidem, pp. 116-147, n..$^{\circ}$ 71, passim. Sobre esse documento do bispo D. Miguel, ver Armando Alberto Martins, O Mosteiro de Santa Cruz de Coimbra na Idade Média. Lisboa, Centro de História da Universidade de Lisboa, 2003, pp. 284-292. Apesar de todos os problemas que a actuação deste bispo para com o mosteiro de Santa Cruz acarretou à Sé de Coimbra, mesmo assim, no séc. XIX Miguel Ribeiro de Vasconcelos, cónego da Sé, escrevia: "Sua memória ainda é lembrada com piedosa recordação nesta Cathédral, para a qual deixou, e para seu anniversario, varios casaes em Arasede e Pertunhos, cujos bens hoje pelas calamidades do tempo nada rendem por levantamento geral dos foreiros."; cfr. Notícia histórica do mosteiro da Vacariça e da serie cronológica dos bispos desta cidade desde 1064, em que foi tomada aos mouros. Lisboa, Tipografia da Academia, 1854-1878, (Cap. II), p. 35. 
4. No que diz respeito ao relacionamento entre instituições eclesiásticas e no que ele pôde apresentar de negativo, ou, mais concretamente, de violento, também a fonte que estudamos nos apresenta um número muito razoável de casos. Contudo, quase se pode dizer que eles têm um denominador comum, considerada uma das instituições intervenientes. De facto, nenhuma outra instituição se apresenta envolvida em mais litígios que a Sé de Coimbra.

Durante o período em questão esteve sempre ocupada pelo mesmo bispo, D. Pedro Soares ${ }^{14}$. Este prelado litigou com várias instituições, mas a mais visada, quer em número de actos, quer em duração das contendas, foi o mosteiro de Santa Cruz, a outra instituição eclesiástica mais poderosa e de maior prestígio na cidade do Mondego ${ }^{15}$. Não admira, por isso, que seja nos documentos que lhe dizem respeito que se achem muitos e significativos exemplos de formas de violência utilizadas em meios eclesiásticos.

Atendendo ao número de documentos que se lhe referem e ainda à violência de que dão testemunho, ocupam também lugar de destaque as contendas que esse bispo sustentou com o bispo eleito da Guarda, D. Martinho, e com o mosteiro de Lorvão.

Quanto às querelas com o mosteiro crúzio, em questão estava a posse de bens e direitos que tanto uma instituição como outra reclamavam. Embora ao tempo de Inocêncio III fossem muitas as questões entre as duas mais importantes instituições da cidade do Mondego, de que a mais grave era, sem dúvida, a que as opunha pela chamada carta de liberdade do bispo D. Miguel e pelos direitos nas igrejas de Leiria ${ }^{16}$, o certo é que havia um conjunto, muito amplo, de circunstâncias que propiciavam esse ambiente de discórdia entre as instituições. Por um lado, alguns mosteiros, como era o caso de Santa Cruz de Coimbra, gozavam

14 Ocupou a cátedra episcopal entre 1192-1233. O testemunho que dele deixou o cónego Pedro Avares Nogueira, no seu Livro das vidas dos bispos da Sé de Coimbra. (Nova edição. Coordenação de Manuel Augusto Rodrigues. Transcrição de Maria Teresa Nobre Veloso. Coimbra, Arquivo da Universidade - G.C. - Gráfica de Coimbra, 2003), pp. 77 e 79, pode considerar-se contraditório. Uma visão moderna da sua acção encontra-se em Armando Alberto Martins, ob. cit., pp. 328-332. Mas não são de ignorar as palavras de Miguel Ribeiro de Vasconcelos: "A sua Prelazia foi um combate contínuo de desgostos e trabalhos, que umas vezes, affastando-o das regras de uma cautelosa e discreta prudência, lhe causarão acerbas afflições (...); ejaz enterrado no Convento de Santa Cruz, onde escolheu sepultura, apezar das antigas desintelligencias que com elle teve, e que lhe custarão tantos desgostos além do dispendio de seus cabedaes" (ob. cit., Cap. III, p. 22).

15 Esta ideia ressalta facilmente do índice ideográfico do Bulário..., p. 492, s.v. "Litígios".

16 Sobre estas duas questões, infimamente ligadas, pode ver-se Ruy d'Azevedo, Documentos Falsos de Santa Cruz de Coimbra (Séculos XII e XIII). Lisboa, edição de José Femandes Júnior, 1932, e Avelino de Jesus da Costa, Bulário..., notas insertas nas páginas 32-34,116-117,163-167, 207-210. 
de prerrogativas e isenções, reais e simbólicas, que, por regra, eram atributo das instituições episcopais; por outro lado, os tempos que se viviam, de guerra e de necessidade uigente de repovoamento, possibilitando a fixação de gentes e exigindo um ordenamento do território, levavam a uma certa competição, concorrência quase diremos, por parte dessas mesmas instituições, na busca de bens materiais e de fixação de direitos que tomavam inevitáveis os conflitos e os confrontos. Isto explica que nos documentos insertos na fonte que analisamos se encontre um conjunto muito vasto de actos de violência, que se estendem também por uma ampla zona que tem Coimbra por centro. Além disso, explica também que muitos desses actos ultrapassem as paredes das instituições intervenientes, para se repercutirem sobre a população campesina, das muitas aldeias cujas igrejas (e respectivos direitos) as instituições eclesiásticas coimbrãs disputavam.

É tudo isto que ajuda a explicar as acusações da Sé de Coimbra contra o mosteiro de Santa Cruz, pela ocupação de igrejas ${ }^{17}$, sua construção em território diocesano, com a reclamação dos respectivos direitos, sempre em manifesto prejuízo da canónica conimbricense, como era o caso de Litém ${ }^{18}$, o ultraje e o prejuízo sentido por os cónegos de Santa Cruz terem ao seu serviço mouros, a quem alugavam casas que obtinham por compra ou doação, na cidade de Coimbra e a quem eles próprios cobravam os direitos devidos à autoridade episcopal. $\mathrm{Ou}$, em atropelo maior, chegaram a fazer construir uma capela dentro dos muros da cidade, na paróquia da igreja matriz (isto é, da Sé catedral), em desrespeito ao bispo e em prejuízo da igreja catedral ${ }^{19}$.

Em tempo de interdito, prior e cónegos crúzios saíam do seu mosteiro e invadiam igrejas, raptavam e matavam os homens, roubavam os gados, arrasavam os campos, como fizeram em Tavarede ${ }^{20}$; sob coacção, que chegava ao uso da própria força, faziam sepultar defuntos falecidos em situação de excomunhão ${ }^{21}$.

Mesmo em tempo normal, recorriam à força e, à mão armada, roubavam homens e gados ${ }^{22}$ ou, por homens seus e em conivência com o poder laico, raptavam clérigos de igrejas da Sé, pretextando crimes contra membros da sua comunidade; vexavam-nos de diversas formas, quer prendendo-os, quer absolvendo-os de excomunhão, para vergonha da Igreja diocesana, como aconteceu com dois clérigos de Arazede ${ }^{23}$.

${ }^{17}$ Como fizeram em Ourém; cfr. Bulário..., p. 339, n. ${ }^{\circ} 188$.

18 Ibidem, pp. 17-18, n. ${ }^{05} .15$ e 16.

19 Ibidem, p. $41, \mathrm{n} .{ }^{\circ} 31$.

${ }^{20}$ Ibidem, p. 19, n. ${ }^{\circ} 17$; para o testemunho da morte de um homem, nesse lugar, ver na p. 144, o depoimento de João César.

${ }^{21}$ Ibidem,?. 31, 181-183, n. ${ }^{\circ} 25$ e 88.

${ }^{22}$ Como haviam feito em Arazede e Cadima; cfr. Bulário..., p. 141, n. ${ }^{\circ} 71$.

${ }^{23}$ Ibidem, p. 39, n. ${ }^{\circ} 29$. 
A parte contrária não ficava isenta dos mesmos erros e atropelos ou, pelo menos, de acusações pela prática do mesmo tipo de atitudes. O bispo e os seus homens eram acusados de roubar cereais e gados do mosteiro, de receber excomungados pelo prior de Santa Cruz, de exigir pagamentos indevidos aos paroquianos de igrejas do mosteiro, como em Cadima, Travanca, Alquerubim, Mira, S. João de Loure, Santa Maria de Taveiro, Louriçal24. Ou, ainda, de invadir paróquias e destruir celeiros, como haviam feito em $\mathrm{Cadima}^{25}$, ou, mais grave, os próprios altares, como acontecera em S. Sebastião de Seia $^{26}$ e Murtede, chegando a lançá-los, por terra, de modo vil, como havia sido feito na segunda destas localidades $^{27}$. E, mais grave ainda, eram acusados de trabalhar, junto do rei (D. Afonso II), contra Santa Cruz, sugerindo que os responsáveis do mosteiro haviam querido desenterrar seu avô, ou de incitar à destruição de um moinho do mosteiro, em seu grande dano.

Como fica claro, muitos destes actos tinham repercussão maior sobre os próprios paroquianos, aqueles que se viam confrontados com os resultados práticos (e negativos) do antagonismo dos responsáveis religiosos.

A este tipo de situações deve juntar-se um outro tipo de violência, muito frequente, praticado por representantes de ambas as partes, que consistia na disputa de cadáveres, aos quais acabavam por dar sepultura. A crermos nos documentos, e nas acusações mútuas entre frades de Santa Cruz e cónegos da catedral de Coimbra, quando morria alguém, normalmente paroquiano de uma igreja pertencente à outra instituição, ou, no caso de ser morador em paróquia da Sé, e, por devoção, deixava os seus bens e escolhia ser sepultado na instituição contrária, logo aparecia algum representante da instituição interessada, reclamando o corpo do defimto e os respectivos direitos ${ }^{28}$; perante a recusa,

24 Para a localização destes bens do domínio de Santa Cruz, ver Armando Alberto Martins, ob. cit., p. 988 (mapa de Localização dos bens de Santa Cruz (adquiridos pelo Prior D. João Teotónio) (1152-1181).

25 Bulário... p. 147, n. $^{\circ} 71$.

26 Actual freguesia de Carragozela, desse concelho.

27 Bulário..., pp. 130 e 141, n. $^{\circ} 71$, respectivamente.

28 Referimo-nos às mandas ou mortuárias, quota-parte, normalmente a terça, dos legados pios dos fiéis. Eram também conhecidas por legados ou terça das mandas. Segundo a norma, deveriam ser pagas à paróquia a que se pertencia (cff. Bulário... p. 53, n. ${ }^{\circ}$ 39). Para uma outra prática, a do recolhimento de leigos ou mesmo clérigos, já idosos, que fazia também ingressar muitos proventos no mosteiro, ver Armando Alberto Martins, ob. cit., pp. 764-765. Chamando à colação exactamente um documento de Inocêncio III (Bulário..., pp. 52-53, n. ${ }^{\circ}$ 38), aduzido pelo Autor, pode dizer-se que esta prática podia também ser fonte de controvérsia entre a Sé de Coimbra e o mosteiro de Santa Cruz. De facto, fica a saber-se que o bispo consultara o papa sobre o direito de continuar a receber os direitos episcopais por parte dos que, assim, se recolhessem 
do lado da parte adversa, não raro os cadáveres acabavam por ser roubados, por vezes sob violência armada, para serem levados a lugar da instituição interessada nos bens legados e direitos devidos.

Apesar de inesperada, pelas instituições suas praticantes, era prática muito frequente dos dois potentados eclesiásticos da cidade de Coimbra, afinal ambos ciosos dos bens que lhes poderiam advir da última vontade dos fiéis e dos direitos que eram pagos a propósito da última necessidade dos homens. Sendo um espelho da rivalidade que cultivavam entre si, por vezes os actos eram acompanhados de tanta violência, que há mesmo referência ao espancamento de um arcediago da Sé, ocorrido num desses $\operatorname{casos}^{29}$. Pela frequência com que é referida esta queixa, parece ser prática muito mais comum do que seria suposto da parte de instituições com o tipo de fim e responsabilidade social que tinham ${ }^{30}$.

Se tudo isto mostra várias facetas da violência, chegada aos extremos como se pode concluir, pode também dizer-se que havia sempre novas formas de ela se apresentar. Nos momentos de tensão, ela subia de tom quando se enfrentavam membros de ambas as instituições da cidade. Disso se queixavam os cónegos da Sé, a propósito de uma cena menos edificante ocorrida à porta do mosteiro de Santa Cruz. Certo dia, quando os homens da Sé passavam nesse local, transportando o pão que lhes deixara certo homem, de nome Aquilino, que cremos morador em Vila Pouca (1. f. Ameal, c. Coimbra), saíram sobre eles homens do mosteiro, clérigos e leigos, tendo-se assistido a uma batalha campal, à pedrada, entre uns e outros ${ }^{31}$. Tal cena de lapidação parece ter deixado eco no meio clerical de Coimbra, pelas muitas referências que lhe são feitas nas peças do processo entre as duas instituições. De uma outra vez, foi o deão de Coimbra que invadiu o capítulo de Santa Cruz (ainda que, da parte da Sé se entendesse que não tinha havido violência ... .) $)^{32}$.

ao mosteiro. Acedendo, no sentido de precaver grave prejuizo, o papa deu resposta afirmativa a essa questão do bispo D. Pedro Soares, adiantando que tais pessoas deviam receber os sacramentos nas respectivas paróquias.

29 Foi a propósito da sepultura de Aldorá Goro lana, paroquiana de Santa Justa, que havia escolhido sepultura em Santa Cruz. Talvez pela violência que suscitou e pelo espancamento do arcediago, deve ter sido um caso que deixou marcas na cidade, pois que está praticamente presente em todos os depoimentos produzidos a propósito das questões entre a Sé de Coimbra e o mosteiro de Santa Cruz, os quais se publicam, na íntegra, na obra que nos serve de apoio. Cfr. Bulário..., pp. 116-149, n. ${ }^{\circ} 71$.

30 Não sabemos se a informação veiculada pelo testemunho do cónego Martinho Roberto (iibidem, p. 125), de que os frades de Santa Cruz tinham tomado noventa e três paroquianos da paróquia de Santa Justa e um número que desconhecia da de Santiago, também se prende com este tipo de prática ou não, mas não custa a crê-lo, em virtude destes casos.

${ }^{31}$ Ibidem, pp. 145, 147 e 148.

32 Ibidem, p. 143 e 147. 
Mas a Sé de Coimbra não se viu envolvida em problemas, configurando actos de violência, apenas com o mosteiro que se ergueu na sua cidade e que lhe foi concorrente nas mercês régias e nas dádivas dos fiéis. Tivemos ocasião de, há anos, estudarmos o processo de passagem do mosteiro de Lorvão de comunidade masculina a feminina e de beneditino a cisterciense. Por isso, não nos deteremos nele, de novo. Mas não podemos deixar de dizer que, também nele, a Sé de Coimbra se não protagonizou nenhum dos actos, directamente, através de qualquer dos seus membros, contribuiu para o clima de violência que aí se viveu, com a secessão da comunidade e acusações entre os seus membros desavindos ${ }^{33}$.

Todos os casos analisados têm como palco ou a cidade de Coimbra ou os seus arredores ${ }^{34}$, locais onde a tarefa do povoamento possibilitava a fixação de gentes e a instalação dos interesses das instituições eclesiásticas.

Porém, não se pense que as questões da diocese de Coimbra se confinaram à cidade ou às suas proximidades. Tendo sido a mais precocemente restaurada a Sul do Douro e a única diocese erecta durante algumas décadas e sem qualquer outra instituição eclesiástica que se lhe pudesse opor, pelo poder e prestígio, não admira que esta diocese se tenha expandido por regiões que, historicamente, nunca lhe haviam pertencido. Ora, à medida que outras dioceses se restauravam e que outras instituições se fixavam no território, eram inevitáveis os conflitos ${ }^{35}$.

${ }^{33}$ Sobre esta questão, veja-se o nosso trabalho Inocêncio III e a passagem do mosteiro de Lorvão para a Ordem de Cister. Separata de Revista Portuguesa de História, XVIII (1980), sobretudo os pontos 4 e 5 . Como fulcral ao processo, salientamos algumas atitudes do bispo, que parecem configurar toda uma atitude de conivência com os interesses do rei e de sua filha, D. Teresa. Além de que é a ele que se deve a acusação de que o mosteiro se encontrava em ambiente de descalabro material e espiritual, juízo que perdurou pelos séculos para justificar a mudança de ocupantes em Lorvão, mas que temos por inteiramente falso. Em relação aos cónegos, pode dizer-se que alguns deles subscreveram o documento do seu bispo, no qual este afirma ter colocado monjas no mosteiro por ser a única maneira de o salvar da má gestão dos frades (cfr. o nosso artigo citado supra, vol. XVIII, p. 264, doc. n. ${ }^{\circ}$ 8). Posteriormente, em Julho de 1211, alguns deles testemunharam a declaração do bispo de Lamego, segundo a qual os monges de Lorvão receberam quinhentos áureos da rainha D. Teresa, para pagamento das dívidas da questão com D. Teresa, declararam não querer reingressar no seu mosteiro e renunciaram aos documentos alcançados do papa e do arcebispo de Compostela, sobre a questão (cfr. Bulário..., pp. 311-312, n. ${ }^{\circ} 163$ ).

34 Exceptua-se o caso, referido também, em Seia. Esta região serrana foi, desde muito cedo, palco de acções de povoamento e, por isso, alvo também dos interesses das instituições eclesiásticas. E se as da diocese de Coimbra se entendem pelo seu papel de responsável eclesiástica das populações, as do mosteiro de Santa Cruz têm de ver-se pela piedade dos fiéis que, com as suas doações, abriam a porta à instalação, pelo território, de outras instituições, com novos interesses.

35 E não se fique com a ideia de que só em Portugal (ou na Península) houve problemas de delimitação de fronteiras diocesanas. O caso foi muito mais geral, encontrando-se exemplos um pouco por todo o Ocidente europeu. Cfr. Jean Gaudemet, Église et cité. Histoire du droit canonique. Paris, Du Cerf/ Montchrestien, 1994, pp. 412-415. 
Pela época em que nos situamos e tendo em vista o amplo espaço a Sul do Douro já sob dominação cristã, o conflito mais violento que a diocese conimbricense enfrentou foi com a diocese da Guarda.

$\mathrm{Na}$ documentação que analisamos, o primeiro sinal de desentendimento claro entre os bispos das duas dioceses surge em Março de 1203, ocasião em que o papa manda aos comissários que então designa a essa causa que examinem as queixas do prelado conimbricense ${ }^{36}$. Por esse documento se conhece, então, que, na ausência de D. Pedro de Coimbra na cúria apostólica, o eleito da Guarda (isto é, alguém por si), com o auxílio do porteiro régio, havia invadido igrejas e bens seculares pertencentes à diocese de Coimbra, bem como, com violência, fizera prender clérigos (que ainda mantinha cativos, na ocasião). Posteriormente, infligira vários tormentos ao próprio bispo. No ano seguinte, uma outra bula, dando conta da continuidade do clima de desentendimento entre os dois prelados ${ }^{37}$, ajuda a objectivar um pouco os actos de violência. Espoliação de igrejas e bens, violência à mão armada sobre clérigos, ameaças, injúrias, roubo de animais (um burro, vinte e duas vacas com três vitelos), tudo é referido neste momento. Num diferendo que se arrastou durante anos, não admira que novos documentos espelhem os actos de violência a que chegavam as questões. Por isso, em 1207, nova bula corrobora o que já se conhecia do processo e indica ainda outras formas de violência que, entretanto, se foram exercendo ${ }^{38}$. Percebe-se agora que a invasão violenta e a ocupação de bens incluía castelos (que, sabe-se por documento posterior, eram os de Seia, Gouveia, Folgosinho, Linhares e Celorico ${ }^{39}$ ) e aldeias, os direitos episcopais que o bispo de Coimbra possuía "in tota Beira et Covilliana", e toma-se conhecimento de que, na ocasião em que o procurador do bispo de Coimbra tomava posse de algumas igrejas, os sequazes do bispo da Guarda, chefiados por um seu sobrinho e com recurso à violência, roubaram as cavalgaduras a dois homens do bispo de Coimbra e agrediram-nos, acabando por feri-los até à morte.

As condições político-militares do território, que referimos acima e que tinham influência sobre as relações entre instituições eclesiásticas foram motivo, parece-nos, de mais um caso que a nossa fonte deixa transparecer. Em 1209, Inocêncio III fazia expedir a bula Dilecti filii, dirigida ao prior de S. Vicente de Lisboa e aos reitores de Santa Maria de Marvila e de S. Julião de Santarém, para obrigarem o mosteiro de Santa Cruz de Coimbra a reparar os males

36 Bulário..., p. 162-163, n. ${ }^{\circ} 86$.

37 Ibidem, pp. 216-218, n. ${ }^{\circ} 102$.

38 Ibidem, pp. 245-252, n. ${ }^{\circ} 125$.

39 Ibidem, pp. 379-386, n. ${ }^{\circ} 216$. Pelo meio, ficavam outras diligências do papa, mas não é delas que tratamos; cfr. Bulário..., pp. 305-308 e 340-342, n. ${ }^{\text {ss }} 161$ e 189, respectivamente. 
causados ao mosteiro de Alcobaça, conhecida a verdade sobre as queixas chegadas à Santa Sé. Sem especificar concretamente tais queixas, o texto do documento deixa perceber que os frades de Alcobaça se haviam queixado de que os monges de Santa Cruz tinham construído uma granja em terra do mosteiro alcobacense, reclamavam os corpos de defuntos que tinham escolhido o seu mosteiro para sepultura, furtavam bens violentamente e procediam de forma injuriosa e prejudicial para com os queixosos e os seus bens. Sem podermos avançar na identificação do problema, parece-nos, contudo, de aceitar que, atendendo à data do documento e tendo em vista a localização dos bens do mosteiro de Alcobaça, o palco destes acontecimentos se deveria situar pela fronteira das terras da diocese de Coimbra com a de Lisboa, precisamente pelas terras de Leiria, onde os bens de Santa Cruz e Alcobaça se tocariam e os interesses se podiam entrecruzar ${ }^{40}$. Seria, pois, mais um caso em que a definição (ou indefinição) territorial dos domínios fundiários das instituições, aliada a toda uma tarefa de povoamento do território em curso e que fazia oscilar os limites territoriais, ajuda a entender o clima de confronto, animosidade e violência em que, muitas vezes, viveram ${ }^{41}$.

5. São estes os principais casos de violência de que as bulas expedidas por Inocêncio III para Portugal nos dão notícia. Contudo, não podemos deixar de observar que elas reflectem outras situações em que se pode adivinhar um

40 Saúl António Gomes vê neste problema uma consequência do "ambiente da crise vivida por Santa C r u z.. c fr. Relações entre Santa Cruz de Coimbra e Santa Maria de Alcobaça ao longo da Idade Média. Aspectos globais eparticulares. Separata de IXCentenário do nascimento de S. Berrnardo. Encontros de Alcobaça e Simpósio de Lisboa. Braga, Universidade Católica Portuguesa - Câmara Municipal de Alcobaça, 1991, p. 267. Pessoalmente, não nos parece, por si só, justificativo deste caso de mau relacionamento. Para nós, ele está no terreno, pelas circunstâncias aduzidas no texto. Para os limites entre os domínios das duas instituições nessa região do território, ver, do mesmo Autor, A população e o povoamento de Leiria do século XII ao XVI. Separata de Leiria-Fátima. Órgão oficial da diocese. Ano III, n. ${ }^{\circ}$ 9, Setembro-Dezembro 1995, p. 259, Mapa 3-0 povoamento em torno de Leiria entre 1150 ca. e 1200. Para a disseminação da propriedade do mosteiro alcobacense, ver Iria Gonçalves, $O$ património do mosteiro de Alcobaça nos séculos XIVe XV. Lisboa, Universidade Nova de Lisboa - Faculdade de Ciências Sociais e Humanas, 1989, pp. 22-23.

41 Mais a Sul, embora os problemas de espaço não se fizessem sentir ainda com tanta acuidade, o certo é surgiam, já por então, problemas da mesma natureza, que, não configurando ainda qualquer confronto aberto, se poderiam encaminhar para tal. É o caso da queixa do bispo de Évora, respondida por bula de Junho de 1216, sobre aqueles (pessoas singulares ou instituições? o documento não é explícito), que dos "loca posita inter te [venerabili episcopo Elborensi] ac eosdem [infidelibus] a fidelibus populantur qui te volente in illis exercere pontificale officium et jura episcopalia exigente malicióse negant loca ipsa esse de diócesi Elborensi, affirmantes eadem spectare ad aliquam cathedralium sedium que ab infidelibus detinentur...”. Bulário..., p. 390, n. ${ }^{\circ} 219$. 
certo clima de uma violência difusa. É o caso das situações de interdito e excomunhão, que poderiam acarretar problemas entre instituições e mesmo entre instituições e população, sobretudo quando esta era instrumentalizada pela instituição fulminada por esse tipo de sentenças. Há algumas bulas que deixam perceber claramente que, nessas circunstâncias, algumas instituições, sem temor ou respeito, "quod se privilegiatos asserunt et nullum interdictum servare debere", tocando os sinos e abrindo as portas, recebiam o povo nos serviços divinos ${ }^{42}$. Parece-nos que, nessas circunstâncias, estava encontrada a oportunidade para alguma convulsão entre eclesiásticos que, não raro, traria consigo algum tipo de actuação popular, mais ou menos violenta. Era a oportunidade para injúrias, ofensas, destituições de clérigos, usurpações de igrejas, algumas vezes levadas a cabo com o concurso de leigos. A situação percebe-se também quando as bulas procuram privilegiar instituições, salvaguardando-as ao abrigo de condições que lhes poderiam ser danosas. É, sobretudo, o caso de algumas ordens militares (Templários ${ }^{43}$ e Calatrava ${ }^{44}$ ) ou quando são a resposta a queixas de umas contra outras, como no caso do arcebispo de Braga, que se queixava sobretudo dos Hospitalários e do seu desrespeito da sentença de interdito ${ }^{45}$.

6.0 elenco dos casos que vimos fazendo completa-se com outras situações que os documentos de Inocêncio III deixam a descoberto e que se prendem com as atitudes violentas de leigos contra membros eclesiásticos, sejam clérigos ou membros de ordens religiosas. Embora, em rigor, não sejam casos da natureza dos que vimos tratando, pois uma das partes não é do estado eclesiástico, o que é certo é que eles só existem enquanto uma das partes lhe pertencia. Por isso o consideramos. Aliás, são muito poucas essas situações, mas valem pelo que, algumas delas, reflectem de práticas sociais estabelecidas. Trata-se de casos de carácter geral e de carácter particular a que se podem ainda juntar dois outros, de carácter institucional, que dizem respeito um, ao conflito entre patronos e instituição eclesisástica, e outro, à grave oposição entre cidadãos do Porto e o seu bispo, D. Martinho Rodrigues.

$\mathrm{O}$ caso geral que assinalamos liga-se a uma prática costumeira e generalizada, em uso na arquidiocese de Braga, que consistia em ferir os clérigos, a golpes de bastão, como satisfação de injúrias ${ }^{46}$. Consultado o papa sobre tal prática, o

\footnotetext{
42 Ibidem, p. 15, n. $^{\circ} 12$;

43 Ibidem, pp. 24-25, 38, 54, 65, n. ${ }^{\text {os }} 22,28,40,43$, respectivamente.

44 Ibidem, pp. 55-59, n. ${ }^{\circ} 41$.

45 Ibidem, pp. 20, 101-102 e 226-227, n. ${ }^{08} 18,59$, 108, respectivamente.

46 Ibidem, p. 229, n. ${ }^{\circ} 110$.
} 
arcebispo obtém como resposta que ela "' "manus injectio etsi non violenta tamen injuriosa videtur cum ille canon non tam in favorem clerici ordinati quam in favorem ordinis clericalisfuerit promulgatus", pelo que, naturalmente, a mandava proibir. De facto, tal prática ia contra os preceitos do direito canónico, que desde o séc. XI vinha reforçando a protecção dos clérigos e anatematizando com a excomunhão os que usassem de violência para com eles ${ }^{47}$.

Quanto aos casos de carácter particular, são bem diversos entre si. Um diz respeito ao rapto de uma mulher, obrigada a casar depois de ter emitido voto de castidade $^{48}$. Não sabemos em que casa religiosa o caso se terá passado, mas somos de opinião de que está ligado a um recolhimento de mulheres dependente de um convento de cónegos regrantes, muito possivelmente de Coimbra ou Lisboa. Fosse como fosse, o que há a colocar em evidência, ao nosso caso, é a violentação da vontade de uma mulher, viúva de um primeiro casamento, fugitiva a um segundo, a que a queria obrigar o poder régio, através de declaração do voto de castidade. Raptada e forçada a casar, tentou a fuga; em vão. Realizado o casamento publicamente, nascidos quatro filhos, esta mulher viveria infeliz e de consciência atormentada, preferindo a anulação do seu matrimónio. $O$ caso retrata bem, parece-nos, o tipo e o grau de violência a que eram submetidas as mulheres: raptos, casamentos forçados, matrimónios desfeitos, consciências atormentadas, que faziam trocar as alegrias e responsabilidades da maternidade pela calma e silêncio dos claustros!

É ainda por intermédio de uma mulher que conhecemos um outro caso de violência de leigos sobre clérigos, chegada a Roma, paradigma de outros existentes, por certo. Uma mulher, não identificada, pediu a sepultura eclesiástica para o seu falecido irmão, que tomara parte na morte de um presbítero. Falecido ele, entretanto, embora tenha reconhecido o excesso do seu acto e se preparasse para se dirigir à Santa Sé, a morte roubou-lhe a oportunidade, impedindo-o de ter concretizado esse desejo. Ao contrário, atirara-o para a ignomínia de ausência de sepultura eclesiástica. A piedade da irmã, aliada a alguma censura social, fizera com que ela se interessasse por interceder por alguma reabilitação da memória do irmão, alcançando-lhe a possibilidade de sepultura eclesiástica ${ }^{49}$.

\footnotetext{
47 Jean Gaudemet, ob. cit., p. 485. Para o caso português, a diocese de Braga haveria de ocupar-se dos clérigos que incorriam em certos crimes, como rapto, furto, homicídio, falsificação de moeda, que os poderiam fazer incorrer na alçada da justiça laica. Cff. Synodicon Hispanum. II. Portugal. Edición critica dirigida por Antonio Garcia y Garcia. Madrid, Biblioteca de Autores Cristianos, 1982, p. 20.

${ }^{48}$ Bulário..., pp. 113-114, n. ${ }^{\circ} 69$.

49 Ibidem, p. 347, n. ${ }^{\circ} 193$.
} 
Quanto às situações envolvendo instituições eclesiásticas e leigos, assinalamos um caso de conflito entre os patronos do mosteiro de S. Simão da Junqueira e o prior do mosteiro e um outro, que opunha um grupo de cidadãos do Porto em conflito aberto com o seu bispo, então D. Martinho Rodrigues.

No primeiro, tem-se conhecimento de que injuriavam e prejudicavam o mosteiro de tal modo que a sua contínua opressão e malícia parecia pretender chegar à sua desolação ${ }^{50}$. Embora isolado na documentação que nos serve de corpus, ilustra bem um tipo de situação de frequência usual, com o seu cortejo de nefastas consequências para as instituições religiosas.

A situação delicada em que nos surge o bispo do Porto é, afinal, já o culminar de outras que, desde o início do séc. XII, tinham vindo a opor os homens do Porto ao seu senhor que era, simultaneamente, o seu bispo. O momento actual prendíale com as graves questões que opuseram o rei de Portugal e o bispo do Porto, das quais os homens-bons do Porto souberam tirar o melhor proveito, afirmandose "como poder civil alternativo" 51 . Na luta que protagonizaram, nesse momento, estão presentes actos de violência para com o bispo e os seus homens (de que se destaca o deão), que se traduziram em desrespeito pelas censuras eclesiásticas, invasão e ocupação de bens, roubo de cavalgaduras, e chegaram à sua prisão, com cadeias de ferro, durante cinco meses, no seu paço ${ }^{52}$.

7. De todos estes casos ressalta um certo clima de perturbação social, alguma violência mesmo, onde os membros do clero são intervenientes, a vários e muito diversos títulos. Ora são agentes activos, ora são passivos, vítimas da violência na sociedade, proveniente dos seus pares ou de leigos, que os desrespeitam por muitas e, umas vezes, fundadas, outras vezes, infundadas razões. Na primeira condição, surgem no seu duplo papel de representantes de instituições ricas, possidentes de bens materiais, mas também de detentores de um poder exclusivo de carácter espiritual, que pode castigar e excluir aqueles que prevaricarem ou se lhe opuserem, ainda que sejam do seu próprio grupo. No primeiro caso, os seus interesses chocam-se, na sociedade, com os de muitos outros, gente secular ou instituições eclesiásticas, todas elas em tempo de afirmação, que passava também pelo alargamento dos domínios territoriais.

50 Ibidem, p. 366, n. ${ }^{\circ}$ 206. Sobre este mosteiro e os seu patronos, ver Sérgio Lira, $O$ mosteiro de S. Simão da Junqueira (dos primórdios a 1300). Vila do Conde, Câmara Municipal, I, 2001, pp. 74-93.

51 Armindo de Sousa, in História da cidade do Porto. Direcção de Luís A. de Oliveira Ramos, Porto, Porto Editora, 1994, p. 239.

52 Colhem-se elementos sobre a violência desta questão em Bulário..., pp. 278-284 e 320321 , n." $143,144,145,146$ e 172, respectivamente. 
Por isso, não é de estranhar o choque, o conflito, quando os seus interesses se cruzavam. No segundo, ficava ténue a fronteira entre desobediência e violência, sendo muito fácil passar de uma à outra. E era-o tanto mais, quanto, dentro do mesmo estado, se todos conheciam as regras, também todos conheciam a malícia que lhes permitia a fuga ao seu cumprimento.

No seu papel de agentes passivos dos actos de violência, fossem eles perpetrados pelos seus pares, fossem cometidos pelos leigos, maus, desrespeitadores, incultos, os eclesiásticos tomavam-se vítimas, algumas vezes das suas próprias faltas, no mau exemplo, na demissão da responsabilidade que lhes cabia como um dos grupos condutores da sociedade.

E por esta última razão, não podemos deixar de equacionar também o reflexo das suas desavenças na sociedade da época.

Por um lado, o clima de violência repercutia-se sobre as populações humildes, aqueles sobre quem recaía o peso do edifício social. Embora os casos que nos surgiram se tenham desenrolado também em espaço urbano, a sua grande maioria teve por palco o mundo rural. Aí se situavam os maiores e mais importantes domínios das instituições eclesiásticas, logo era um espaço mais propício ao confronto. E se isso não é deveras significativo, porque a sua importância vem do seu grau de violência e do seu impacto no meio em que eles se desenrolavam, em qualquer dos cenários eles contribuíam para aumentar o clima de medo que caracterizou os tempos medievais. Talvez que no mundo rural os actos de violência ganhassem outra dimensão, pelo seu carácter mais fechado e, sobretudo, quando eles afectavam os bens, as casas, as colheitas, os celeiros. Então, era a já de si periclitante estabilidade que ficava em perigo, com todos os medos que lhe estavam associados.

Por outro lado, a par de uma pequena nobreza, irrequieta, cada vez mais mercenária ${ }^{53}$, porque sem meios de sobrevivência próprios e suficientes, a massa campesina apresentar-se-ia como um meio humano propício para os clérigos fazerem proceder ao recrutamento dos homens de que necessitavam para concretizarem muitos dos actos de violência que eles próprios pretendiam ver praticados. Tudo isto, sem a consciência do seu papel e da sua responsabilidade na sociedade.

Praticados por alguns, reprovados, estamos em crer que por muitos mais, os actos de violência levados a cabo por clérigos ou sob sua incitação, perpetrados sobre instituições eclesiásticas ou sobre os seus membros, atingindo mais ou menos profundamente a sociedade em que se inseriam, fazem parte de todo um tempo de rudeza e de conflitos.

53 Nos documentos surgem, por vezes, referências a milites, que estão sempre entre os agressores. 
Ainda que praticados ou emanados do mundo clerical, eles ultrapassam-nos, pois que brotam do mais fundo da natureza humana, da sua fraqueza e da sua imperfeição. Só demonstram que, mesmo entre aqueles cuja vida era suposto ser consagrada ao louvor de Deus, havia lugar à desavença, à discórdia, ao ódio e à vingança ${ }^{54}$.

Mas não podemos deixar de reflectir também que entre tantas instituições eclesiásticas (e eram algumas (poucas) dezenas) e tantos e tantos (e seriam centenas) membros do clero, os casos que apresentamos são uma ínfima minoria, em comparação com o protagonismo brilhante de outras instituições ou mesmo de facetas da vida daquelas que aqui considerámos, ou com aqueles que tendo escolhido o estado clerical, tiveram vidas de fidelidade à sua vocação. Também aqui a excepção confirma a regra e a falta de vocação, aliada às dificuldades dos tempos, sem ser justificação, podem ajudar a explicar muitos dos casos. 